\title{
Detecting Structural Breaks: Exchange Rates in Transition Economies
}

\author{
Evžen Kocenda \\ CERGE-EI, Prague, Czech Republic, \\ W. Davidson Institute at the University of Michigan Business School, \\ CEPR, London
}

\begin{abstract}
:
The aim of this paper is to provide evidence about the existence or non-existence of structural breaks in exchange rates of European transition economies. We used the testing procedure of Vogelsang (1997) that allows for detecting a break at an unknown date in the trend function of a dynamic univariate time series. The procedure does not impose restrictions on the nature of data since it allows trending and unit-root regressors. The results depend in a striking way on the economic climate of a particular country. In Balkan countries, which belong to less stable economies, the measures adopted by monetary authorities indeed brought about a structural break in exchange rate behavior. In more stable transition economies, such as those in Central Europe, the monetary steps tended to stabilize the exchange rate behavior. Finally, the exchange rates of the Baltic countries offer mixed results.
\end{abstract}

\section{Abstrakt:}

Cílem tohoto clánku je najít dukazy pro ci proti existenci strukturálních zmen v menových kurzech transformacních ekonomik. Použili jsme test vyvinutý Vogelsangem (1997), jenž umožnuje detekovat zmenu v trendu dynamické casové rady jedné promenné bez toho, že by bylo datum zmeny predem známo. Test neklade žádná omezení na povahu použitých dat, nebot umožnuje pracovat jak $s$ radami které obsahují trend, tak s temi které mají jednotkový koren. Výsledky testu $v$ prekvapivé míre závisí na ekonomické situaci $v$ té které zemi. V Balkánských zemích, které se radí mezi pomaleji se trasformující ekonomiky, opatrení menových orgánu casto vyvolala strukturální zmenu v menovém kurzu. Ve více stabilních ekonomikách, jako jsou ty ve strední Evrope, monetární opatrení obvykle menový kurz stabilizovala. Menové kurzy Baltských zemí nabízejí smíšené výsledky.

Keywords: exchange rate, transition, structural change, monetary policy

JEL Classification: C12, F31, P52

I would like to thank Jan Hanousek, Mirek Lízal, Štepán Cábelka, and participants of the ACE workshop for helpful comments. The research support of the ACE grant P96-6095-R is gratefully acknowledged. The usual disclaimer applies.

Correspondence to: Evžen Kocenda, Center for Economic Research and Graduate Education (CERGE), Charles University, P.O.Box 882, Politických veznu 7, 11121 Prague, Czech Republic, tel. (420-2) 24005149, fax (420-2) 24227143, e-mail: evzen.kocenda@ cerge.cuni.cz 


\section{Introduction and Motivation}

This paper attempts to analyze the trend behavior of both nominal and real exchange rates of eleven Central and Eastern European Countries (CEE). The question of whether a structural break occurred in the exchange rate evolution is of specific interest. An exchange rate and its regime are important elements in the overall monetary policy of each country. Its significance is even more accentuated in the case of transition economies. This is due to the fact that international lending institutions like the International Monetary Fund, World Bank, and European Bank for Reconstruction and Development (EBRD) provide credit subject to macroeconomic stability and a stable exchange rate. This is true no matter what kind of regime is adopted.

Any country in transition must undergo a stage of macroeconomic stabilization, which is inevitably accompanied by large shocks to macroeconomic fundamentals. The nature and magnitude of these disruptions affect the progress of economic development. Research into the success of the stabilization programs in transition economies is especially important for policymakers. Owing to the relative openness and the close economic relations between transition economies in Central and Eastern Europe and between these countries and the European Union, the trend behavior of the exchange rate and the exchange rate regime play an important role in the economic development of the CEE countries towards sustainable growth.

The issue of trend behavior of exchange rates has been widely discussed in recent literature. Mostly it has attracted interest with respect to research associated with questioning the validity of purchasing power parity. Such an approach can be found in Hegwood and Papell (1998), Wu (1997), Culver and Papell (1995), and Flynn and Boucher (1993) among others. The majority of the previous research has found significant estimates of the break parameters. When the break points or margins of structural instability are taken into account, then most of the exchange rates could be modeled as stationary around a broken trend.

Stock and Watson (1996) have recently provided ample evidence that a large set of macroeconomic variables is subject to structural instability. Exchange rates might be affected by one-time shocks generated by structural changes in the underlying economies and/or measures taken by policy-making authorities. During the transition process many crucial steps performed by authorities are likely to either cause or aid in bringing a kind 
of structural change. A change in an exchange rate regime and/or official modification of an exchange rate level might be mirrored by a structural break in the evolution of an exchange rate.

The aim of this paper is to provide evidence about the existence or non-existence of structural breaks in exchange rates series during transition, as the process has advanced considerably. ${ }^{1}$ We will use a rigorous testing procedure to answer the following questions: (1) whether there was a break or not, and if yes, when it occurred; (2) whether a break coincides with an administrative step associated with an exchange rate or its regime; and (3) whether the timing of a break coincide for both the nominal and real exchange rate. In doing so, we will attempt to shed some light on the trend behavior of exchange rates during transition. In no respect do we intend to make conclusions regarding the performance of national banks in transition countries. The monetary policy executed by any national bank is a too complex set of actions. With respect to changes in the trend behavior of exchange rates, we will point only to a subset of these actions.

Recent innovations in time-series econometrics provide appropriate devices for analyzing the subject of structural change. Perron (1989) has accounted for structural change in a time series by adding a dummy variable corresponding to a pre-determined break date to the augmented test of Dickey and Fuller (1979). Perron and Vogelsang (1992) endogenize the break date for non-trending data in a subsequent work. Later Bai (1997) and Bai and Perron (1998) proposed a technique that enables one to estimate breaks either simultaneously or sequentially in cases of non-trending and regime-wise stationary data. Zivot and Andrew (1992) suggested a test for a unit root that allows for a one-time change in the constant and/or in the slope of the trend function of the series.

For this paper we opted to use the testing procedure devised by Vogelsang (1997). The test statistics allows for detecting a break at an unknown date in the trend function of a dynamic univariate time series. The advantage of the procedure is that it does not impose restrictions on the nature of data since it allows trending and unit-root regressors. The procedure does not impose any parametric specification of distribution. The existence of the fourth moment is a standard assumption for a certain asymptotic parameter and the specification of a wide class of distributions is ensured.

\footnotetext{
${ }^{1}$ We do not associate our research of trend behavior of exchange rates of the CEE countries with questioning the validity of purchasing power parity.
} 
The rest of the paper is organized as follows. Section 2 presents formally the testing procedure used. Section 3 describes the data including their basic statistics. Section 4 brings forth empirical findings and is then followed by a brief conclusion.

\section{Technique to Detect Structural Breaks}

For the purpose of econometric analysis the real exchange rates $Q_{t}$ of national currencies in relation to the US Dollar and the Deutsche Mark were constructed in the usual manner as

$$
Q_{t}=\left(E_{t} \cdot C P I_{t}^{*}\right) / C P I_{t}
$$

where $Q_{t}$ is the defined real exchange rate, $E_{t}$ is the nominal exchange rate of a domestic currency per one unit of a foreign currency, $C P I_{t}$ is the domestic consumer price index $(\mathrm{CPI})$, and $C P I_{t}^{*}$ is the foreign CPI.

In order to detect trend breaks in the data we use a Wald-type test suggested by Vogelsang (1997). We adhere to the original notation of the testing procedure that considers the following data-generating process for a univariate time series process, $\left\{y_{t}\right\}_{l}^{T}$, with a break in trend at unknown time $T_{b}^{c}$,

$$
\begin{aligned}
& y_{t}=f(t) \theta+g\left(t, T_{b}^{c}\right) \gamma+v_{t}, \\
& A(L) v_{t}=e_{t},
\end{aligned}
$$

where $\quad f(t)=\left(1, t, t^{2}, \ldots, t^{p}\right), \quad g\left(t, T_{b}^{c}\right)=l\left(t>T_{b}^{c}\right)\left\{1, t-T_{b}^{c},\left(t-T_{b}^{c}\right)^{2}, \ldots,\left(t-T_{b}^{c}\right)^{p}\right\}$, $\theta=\left(\theta_{0}, \theta_{1}, \ldots, \theta_{p}\right)^{\prime}, \quad \gamma=\left(\gamma_{0}, \gamma_{1}, \ldots, \gamma_{p}\right)^{\prime}, \quad A(L)=1-a_{1} L-\ldots-a_{k+1} L^{k+1}$, and $l($.$) is the$ indicator function. The autoregressive polynomial $A(z)$ is assumed to have at most one real valued root on the unit circle and all others strictly outside the unit circle, and the error process $\left\{e_{t}\right\}$ is assumed to be i.i.d. $\left(0, \sigma_{e}^{2}\right)$ with finite fourth moment. Under (2) and (3), $\left\{y_{t}\right\}$ is an autoregressive, stationary or unit root process around a $p$ th-order deterministic time trend with a break at date $T_{b}^{c}$. The null hypothesis of a stable trend 
function is given by $H_{0}: \gamma=0$. Under the alternative, at least one of the trend polynomials has a break, $H_{1}: \gamma_{i} \neq 0$ for at least one $i=0,1, \ldots, p$.

Vogelsang (1997) further shows that using $A(L)$ and the ADF factorization, (2) can be rewritten as

$$
\Delta y_{t}=f(t) \beta+g\left(t, T_{b}^{c}\right) \delta+d\left(t, T_{b}^{c}\right) \eta+\pi y_{t-1}+\sum_{i=1}^{k} c_{i} \Delta y_{t-i}+e_{t}
$$

where $d\left(t, T_{b}^{c}\right)=\left\{l\left(t=T_{b}^{c}+1\right), l\left(t=T_{b}^{c}+1\right), \ldots, l\left(t=T_{b}^{c}+k\right)\right\}, \eta=\left(\eta_{1}, \eta_{2}, \ldots, \eta_{k}\right)^{\prime}$, and $\beta, \delta$, and $\eta$ are implicitly defined by $f(t) \beta=A(L) f(t) \vartheta$ and $g\left(t, T_{b}^{c}\right) \delta+d\left(t, T_{b}^{c}\right) \eta=A(L) g\left(t, T_{b}^{c}\right) \gamma$.

Because the one-time dummy variables $d\left(t, T_{b}^{c}\right)$ are asymptotically negligible, it may be optional to eliminate them. ${ }^{2}$ Then, under the null hypothesis of no structural change $H_{0}: \gamma=0$, it directly follows that $\delta=0$. Therefore, test statistics can be constructed by estimating (4) and testing the hypothesis that $\delta=0$. Writing the model in a form given by (4) is useful because serial correlation in the errors is handled by including enough lags of $\Delta X_{t}{ }^{3}$ Such a test is possible to perform routinely in unit root testing.

$$
\Delta X_{t}=\alpha+\beta_{1} t+\beta_{2} t^{2}+\theta D U_{t}+\gamma_{1} D T_{t}+\gamma_{2} D T_{t}^{2}+\eta X_{t-1}+\sum_{j=1}^{k} c_{j} \Delta X_{t-j}+\varepsilon_{t}
$$

where $X_{t}$ is an exchange rate, either nominal or real as defined earlier. The dummy variables for structural breaks bear the following values: $D U_{t}=1$ if $t>T_{B}$ and 0 otherwise, $D T_{t}=t-T_{B}$ if $t>T_{B}$ and 0 otherwise, and $D T_{t}^{2}=\left(t-T_{B}\right)^{2}$ if $t>T_{B}$ and 0 otherwise.

The exact specification of the test depends on what type of a trend is present in the data. We have essentially three options. If both a linear and a quadratic trend is allowed, equation (5) is estimated as written and this specification is called Model I. For linear trending data where the quadratic trend is absent, Model II imposes the restrictions that

\footnotetext{
${ }^{2}$ See Vogelsang (1997).
} 
$\beta_{2}=\gamma_{2}=0$ and equation (5) is estimated with this restriction taken into account. Model III is used for non-trending data where both linear and quadratic trends are absent. The equation (5) is then estimated with restriction $\beta_{1}=\gamma_{1}=\beta_{2}=\gamma_{2}=0$. While tests for non-trending and linear trending data are more common, inclusion of the quadratic trend in Model I may be particularly appropriate.

In our analysis the equation (5) is estimated sequentially for each break period with 1 percent trimming, i.e., for $0.01 T<T_{B}<0.99 T$ where $T$ is the number of observations. Vogelsang (1997) reports critical values for both 1 and 15 percent trimming. The 1 percent trimming was used in our analysis because we did not want to miss the influence at the beginning or end of the sample. To evaluate the significance of parameters, we use the critical values tabulated in Vogelsang (1997). For Model III, $\operatorname{Sup} F_{t}$ is the maximum, over all possible trend breaks, of three times the standard $F$-statistics for testing $\theta=\gamma_{1}=\gamma_{2}=0$. For Model II, $\operatorname{Sup} F_{t}$ is the maximum of two times the standard $F$ statistic for testing $\theta=\gamma_{1}=0$ and, for Model I, $\operatorname{Sup} F_{t}$ is the maximum of the $F$-statistic for testing $\theta=0$. It is important to understand that the break periods are determined endogenously with no ex ante preference given to any particular period. These tests allow for only a single break in each series. Tests which allow for multiple breaks, such as Bai and Perron (1995) have, to our knowledge, only been developed for stationary and non-trending data.

The no-trend break null is rejected in favor of the broken-trend alternative if the SupFt statistic is greater than the appropriate critical value. Vogelsang (1997) tabulates critical values for both stationary and unit root test series. We estimate three versions of Augmented-Dickey-Fuller tests, with a constant, a linear, and a quadratic time trend. Using these tests, we can reject the unit root null in only about 10 percent of the cases (at the 5 percent significance level), and so use the unit root values. Since the unit root critical values are higher than the stationary critical values, we are erring on the conservative side if the data is actually stationary.

The structural change literature provides little guidance regarding which model to estimate. If the data is trending (either linear or quadratic), then estimating a model which does not contain the appropriate trend may fail to capture a significant break. On the other hand, the power to reject the non-trend-break null when there is a break is

\footnotetext{
${ }^{3}$ The appropriate number of lagged differences $(k)$ in equation $(5)$ is determined using the parametric method proposed by Campbell and Perron (1991) and Ng and Perron (1995).
} 
reduced when estimating a model which includes a trend which is not contained in the data (because the critical values increase with the inclusion of more trends). We used the model selection algorithm described in Ben-David and Papell (1997) and estimated the least restrictive Model I that contains both linear and quadratic trends.

\section{Data}

The study uses data from the following eleven countries: the Czech Republic, Hungary, Poland, Slovakia, Slovenia, Albania, Bulgaria, Romania, Estonia, Latvia, and Lithuania. The time span of the data is from January 1991 to December 1997. The monthly average exchange rates of respective national currencies were obtained from the Bank for International Settlements, Basle; the International Monetary Fund's International Financial Statistics; and the EBRD. The monthly consumer price indices were obtained from the latter two sources. The reports of the national banks of each country in question were consulted as well. Figures $1-4$ illustrate the evolution of both nominal and real exchange rates during the researched period.

Table 1 summarizes the basic statistics, average and standard deviation, of the nominal exchange rate for both the US dollar and Deutsche mark. Standard deviations reveal a remarkably high volatility of the national currencies of Romania and Bulgaria. This is in a sharp contrast with the other countries, specifically the Baltic and part of Central Europe. It is also evident without exception that standard deviation is lower for the exchange rates of the Deutsche mark. The stable mark gained additional stability over time through the Exchange Rate Mechanism and its volatility has been lower that that of the US dollar. Because the majority of the CEE currencies was, during the researched period, under regimes that were in various ways bound to the Deutsche mark, we claim that this is the reason for "transferred" lower volatility in the exchange rates in question.

Table 2 presents the basic statistics for real exchange rates. Standard deviation decreased dramatically for the majority of the currencies, including those cited above. A certain increase occurred in the cases of the Czech Republic, Slovakia, and Estonia. Again, standard deviation is clearly lower for exchange rates of the Deutsche mark.

From the very beginning of the transition process in Central and Eastern European economies, exchange rate behavior and associated exchange rate regimes were closely monitored. The choice of a particular exchange rate regime is one of the major policy 
decisions transition countries had to make. ${ }^{4}$ Exchange rate regimes and the evolution of nominal exchange rates relative to major currencies differ widely across these countries. The Czech Republic and Slovakia favored the semi-fixed regime of a basket peg, while Hungary moved from an adjustable peg to a pre-announced crawling band in 1995, and Poland moved from a fixed basket peg to a crawling basket peg. Many other countries in the region favored a managed float or a currency board. Table 3 summarizes the types of exchange rate regimes that the CEE countries have adopted since their economic transition. Since Table 3 offers merely a sketch of variations in exchange rate regimes, the annual reports of national banks of the CEE countries are suggested as an ultimate reference. The other specific measures adopted by monetary authorities that may influence trend behavior of the exchange rate in a particular country and period are specified in the next section.

\section{Empirical findings}

Before we present our empirical findings, several issues should be brought up to help interpret the results. As we mentioned in Section 2, the test is able to detect structural change within the time series data without having imposed restrictions on their detrending or stationarity. By the construction of the test the $\operatorname{Sup} F_{t}$ statistic is computed; however, it has to be understood that not every peak within the data could be labeled as a dramatic point of a change. Firstly, to indicate a structural change, the magnitude of such a peak would have to be enormous. Secondly, even a quite high peak within the data does not need to coincide with a point when a true structural break occurs.

On the other hand several large peaks that occur within a short period of time may increase volatility but they do not necessarily cause structural change. Structural change itself is not related to magnitude of volatility. However, in such a case the test is less likely to detect a structural break because high volatility or variance lowers the power of the test to detect a structural change in the data. By inspecting Figures $1-4$ we can almost surely disregard the outlined scenario.

In several cases the findings based on the test do not exactly correspond to the date when an event took place that could be attributed as a cause of a change. In this paper

\footnotetext{
${ }^{4}$ For further discussion see Edison and Melvin (1990), Edwards (1993), Quirk (1994), Begg (1996), and Sachs (1996), among others.
} 
we are trying to identify an institutional act as a possible cause of a change. It has to be understood that an institutional act is usually anticipated by the market since it is discussed at the policy-making level prior to the time when it is enacted. Information contained in the discussions is then in its discounted version transposed to affect the actions of various market players. From the previous it follows that a sudden act is likely to be fully revealed as a change. We expect that a sudden devaluation by loosening price controls will be shown. The step that is not sudden in its nature is likely to be suppressed because of anticipations and expectations.

When commenting on our results we had to describe the monetary situation in a particular country in greater or lesser detail. The extent of such description has depended on various aspects of the economic environment including elements of monetary policy that were deemed essential for understanding the presence or absence of structural breaks.

\subsection{Central European Countries}

\subsubsection{Czech Republic}

The Czech Republic freed its exchange rate in late May of 1997 after several years of a currency basket peg regime. The test did not reveal any structural change in both the nominal and real exchange rate during the researched period.

\subsubsection{Hungary}

A break of a lower significance level occurred in February 1995 for the nominal rate. The Hungarian national currency, the forint, (HUF) belongs among the closely watched currencies and in 1995 the National Bank of Hungary exercised a strict regime to control its evolution.

The purpose of introducing the announced crawling peg as the new exchange rate regime was to sustain increased competitiveness achieved by the significant initial adjustment of the exchange rate and hence calm speculation against the national currency. The forint was devaluated daily under the regime, and the monthly average calculated by adding the daily depreciation was announced in March 1995, forecasting a monthly devaluation rate of $1.9 \%$ until the end of the first half of the year and $1.3 \%$ from then till the end of the year. The rate of the crawl set for 1995 in line with the projected 
course of consumer price inflation served as an intermediate target for monetary policy and also to prevent inflationary outlook from overheating.

Altogether, the forint was devaluated against the basket of currencies at a rate of $29.86 \%$ in 1995, including 3.4\% in January and February, 9\% in March, and $14.9 \%$ due to the crawl. Thus, we can conclude that the break in the nominal rate path coincided with the series of three devaluations of the forint in the first quarter of 1995. Steady devaluation followed afterwards in conjunction with the implemented crawl regime.

\subsubsection{Poland}

The test did not reveal any break in trend behavior of the Polish zloty (PLN), except in the case of the real rate for US dollars (USD) in February 1994. For this fact we may offer an explanation based on the claim of the National Bank of Poland that attributed the increased share of Polish exporters on foreign markets to the relevant depreciation of the zloty in the beginning of 1994 which resulted from the nominal devaluation of the zloty as of August 1993. However, we do not hypothesize why the break did not occur in the case of the Deutsche mark (DEM) as well.

\subsubsection{Slovakia}

In the beginning of July 1993 Slovakia devalued its national currency, the Slovak koruna (SKK), by $10 \%$. This move happened at a time when the nation's foreign exchange reserves were about 1.33 billions USD. The National Bank of Slovakia denied that the state of the reserves was the main reason for its move and justified the devaluation by the gap between the amount of money in circulation and the demand for it and by an attempt to encourage exports. The break coincided with the devaluation but it was detected only in the case of nominal rate and only for USD.

\subsubsection{Slovenia}

The trend break materialized in August 1992 in the case of the real Deutsche mark exchange rate. We have not been able to uncover a reason for it so far.

\subsection{Balkan Countries}

\subsubsection{Albania}


A trend break materialized in July 1992 for both nominal and real exchange rates, as well as for both denominating currencies. The break date coincides with the time when the Albanian national currency, the lek (ALL), entered a managed float regime and experienced $100 \%$ devaluation at the same time. Such a radical step in monetary policy fully justifies the materialization of a break in trend behavior of the exchange rate.

\subsubsection{Bulgaria}

In the case of Bulgaria the break was recorded in January 1997 for the nominal rate and in 1991 for the real rate of its national currency, the leva (BGL). During 1991 inflation was more or less steadily rising. The prominent event of this year was the fact that on February 18, 1991, a foreign exchange market started functioning in Bulgaria, based on the same mechanism as those in countries with convertible currencies. This was the market mechanism of a free (floating) quotation of the major exchange rates to the leva by commercial banks, and the daily fixing of the central rate by the Bulgarian National Bank (BNB).

At the opening of the market there was a leap in the exchange rate and a large difference between the buying and selling rates-an average of about 2-3 leva for the US dollar, or about $10 \%$ of the exchange rate. After the initial natural fluctuations there came both a stabilization of the rate, and a narrowing of the spread which, as early as the first half of March 1991, fell below 1 leva, or below 5 per cent of the exchange rate. An active participation of the BNB in the foreign exchange market followed. It made the gab between the buying and selling rates smaller. Foreign currency transactions between commercial banks was the most important element of the interbank market from April to the end of May. After the BNB's presence on the market had led to a relatively long period of exchange rate stability and of a spread below 0.5 leva, or between 1 and 3 per cent of the US dollar exchange rate, the market between commercial banks evolved, at first hesitantly, and then more steadily. Consequently the BNB's participation in the market had a two-fold result - stabilization of the exchange rate, and an organizational development of the foreign exchange market towards its transition from a formal into a real interbank market.

Despite stabilization efforts, by the end of 1991 the currency depreciated one third from its highest exchange rate level in March of that year. We are not able to explain the two breaks for real exchange rate which occurred half a year apart in 1991. 
Throughout the years both the political and economic situation of Bulgarian worsened. The political crisis of early 1997 prompted a sixfold devaluation of the leva, from 500 BGL/USD to $3000 \mathrm{BGL} / \mathrm{USD}$. After the political crisis was solved the exchange rate came to a level of 1500 BGL/USD. Later the currency began to gradually depreciate, reaching a level of $1700 \mathrm{BGL} / \mathrm{USD}$ by the end of the half-year when a currency board was introduced. As of July 1, 1997, BNB started to quote daily, by 3 p.m. Bulgarian time, the central exchange rates for foreign currencies to the Bulgarian leva for the next working day based on the fixing set on the Frankfurt Exchange. The arrangement fixed the exchange rate at $1000 \mathrm{BGL} / \mathrm{DEM}$ which corresponded to $1744.1 \mathrm{BGL} / \mathrm{USD}$ for the beginning of the next trading day under the new regime.

The break recorded in January 1997 for both nominal rates fits the situation described above exactly. The break materialized due to the massive devaluation of leva.

\subsubsection{Romania}

The test indicated a break in the nominal exchange rate path for both currencies in December 1996. The break was due to the dramatic economic development that was followed by the administrative measure applied to the foreign exchange market.

During the first half of 1997, the Romanian currency leu (ROL) dramatically depreciated following the government's decision to liberalize the foreign exchange markets. Since December 1996 the exchange rate spiked towards 8000 ROL/USD in February 1997 and then tended to stabilize around 7000 ROL/USD during the first half of the year. The spike of the beginning of 1997 amounted to nearly $100 \%$ nominal depreciation.

In the first half of 1997, a new inflationary shock struck Romania as a consequence of the price liberalization performed by the government. Substantive increases in the CPI index started in December 1996, peaked in March 1997 and then started to stabilize. From the midyear 1996 to the end of the first half of 1997, the CPI rose by $177.4 \%$.

During the same period the nominal depreciation was offset by inflation amounting to a similar magnitude. For this apparent reason the break did not materialize in the case of the real exchange rate.

\subsection{Baltic Countries}

\subsubsection{Estonia}


The break occurred in July 1992 for both the real exchange rate and in September 1992 for the nominal rate but only in the case of the Deutsche mark. The timing of the break is closely related to monetary reform in the country. The Bank of Estonia implemented monetary reform in June 1992. As from June 20, 1992, the only legal tender on the territory of the Republic of Estonia has been the Estonian kroon (EEK) and the Russian rouble (RUB) ceased to function as an official currency. Each person included in the list of residents who has checked his/her name thereon, could on one occasion only exchange up to 1,500 roubles according to the exchange rate of 10 roubles for 1 kroon. Further, till July 1, cash exceeding 1500 roubles could be exchanged at the rate of 50 roubles for 1 kroon. As a part of the monetary reform, the Bank of Estonia adopted the currency board exchange rate regime. The official rate of the Estonian kroon was set at 1 kroon for 0,125 Deutsche mark, or 1 DEM = 8 EEK, from June 20, 1992.

After the currency reform and until Dec 1992 the Bank of Estonia decided to gradually increase the rate of minimum required reserves deposited by commercial banks with the central bank from the former $10 \%$ to $15 \%$. We suspect that such a decision aided the liquidity crisis that erupted in the fall of 1992 and was followed by a crisis in the banking sector. Banking problems in Estonia surfaced boldly in November and on November 18, 1992, the Bank of Estonia issued memorandums to three big banks and blocked their current accounts.

\subsubsection{Latvia}

The break materialized at different dates for nominal and real exchange rates. The test revealed a break in nominal rate for both currencies during the period of February March 1993, and a break in the real rate for both currencies during the period of September - October 1992. Since a measure related to the exchange rate regime was adopted in July 1992, we provide an outline of a very complicated monetary situation in the country for a pertinent period of time during 1992 and 1993.

In the first four months of 1992, Latvia was adversely affected by the inflation of the Russian rouble. To resolve the problem, from May 7, 1992, Latvian roubles (LVR) were put into circulation in Latvia as a legal tender parallel to the existing rouble notes of the Former Soviet Union (SUR). It was declared equal in value with the Russian rouble. Russian roubles in circulation were increasingly substituted by Latvian roubles. 
With the inflation level in Latvia decreasing gradually and hyperinflation beginning to appear in Russia, the exchange rate of the Latvian rouble to the Russian rouble remained at 1:1 despite the fact that the demand of the latter was significantly lower than the supply. This led to a disadvantageous situation for the circulation of Latvian money. To prevent this, in accordance with the respective resolutions, on July 20, 1992 the Latvian rouble became the only acceptable tender in Latvia. In July 1992 the Bank of Latvia introduced a managed float currency regime that was in reality a peg to the Special Drawing Rights (SDR).

The Bank of Latvia with its monetary policy has been able to prevent hyperinflation and to stabilize the Latvian rouble. While in the first half of 1992 the inflation rate was $146 \%$ quarterly, in the two last quarters it decreased to 55.6\%. By December, the inflation was reduced to $2.6 \%$. To stabilize the exchange rate of the Latvian rouble, the Bank of Latvia actively participated in convertible currency markets. Despite this, the largest depreciation of the currency occurred during September and October 1992. At the end of December, the Bank of Latvia sold US dollars to banks at the exchange rate of 167 Latvian roubles per US dollar.

On March 5, 1993, the national currency was renewed. A gradual replacement of Latvian rouble by lat (LVL) started simultaneously, and proceeded until June 28, 1993, when the regulation came into effect stating that all prices, tariffs and balances of accounts shall be calculated in lats. This marked the completion of the currency reform initiated in 1992.

In 1993, the main objective of the monetary policy pursued by the Bank of Latvia was to ensure a low rate of inflation and a stable exchange rate for the national currency. The consumer price index in 1993 was relatively low - 134.9\%, compared to 1992 when it was $1,058.6 \%$. The average monthly rate of inflation was only $1.5 \%$ during the first nine months of 1993. However, during the last quarter of 1993 , the rate grew to $6.2 \%$ monthly. The growth may be explained by the increase in the turnover tax and the excise tax, seasonal price fluctuations and measures taken to protect the domestic market.

The currency reform initiated in 1992 was continued in 1993. The transition to a permanent national currency was gradual, and there were no restrictions on the exchange of the old money for the new. As it was mentioned earlier, introduction of national currency, the lat, started in March 1993. The lat were supposed to replace Latvian temporary currency, the Latvian rouble. Although the Latvian rouble had been stable, 
just before the introduction of the lat there was some turbulence in the market due to the uncertainty regarding the reform, i.e., the introduction of the lat. The population was concerned about the rumors hinting on some kind of confiscatory reform when only Latvian roubles would be exchanged for lats but not Russian roubles. Such behavior prompted a shift from the latter to the Latvian rouble before the reform.

We suppose that the break in 1993 was closely related to the introduction of the new national currency. We also suppose that the break in 1992 was allied to a dramatic drop in inflation towards the end of the year.

\subsubsection{Lithuania}

After detaching itself from the former Soviet Union, Lithuania introduced a temporary currency, the talona, in May 1992. This step was not paired with a strong monetary commitment, though. The monetary policy remained very weak all year and the country recorded the highest inflation during the transition so far. In 1992, the average annual inflation rate increased dramatically to $1,020.8 \%$. The central bank, Bank of Lithuania, introduced the floating exchange rate regime in October 1992 and the talona depreciated considerably against the dollar during the last quarter of 1992 and first quarter of 1993.

Monetary reform was implemented in 1993 and the Bank of Lithuania introduced the new national currency, the lita (LTL), in June 1993. After the reform the Bank of Lithuania started to demonstrate its power in coping with inflation and the lita was stable during the third and fourth quarters. The year-to-year inflation in 1993 reached $410.2 \%$ and then declined considerably to $45.1 \%$ in $1994,35.7 \%$ in $1995,13.1 \%$ in 1996 , and $8.4 \%$ in 1997.

Although inflation was controlled, it remained a stubborn problem. The sudden increase in inflation in 1992 destroyed the savings of the overwhelming majority of the population. The results of the test indicate that the break that was detected in December 1992 should be attributed to the considerable devaluation of their temporary currency, the talona. The devaluation and a break itself was preceded by introducing a floating exchange rate regime. The weak monetary policy should be viewed as a catalyst behind the structural break as well.

\section{Concluding Remarks}


We attempted to analyze the trend behavior of both nominal and real exchange rates of eleven CEE countries. Both kinds of exchange rates are expressed per US dollar and Deutsche mark. The aim of this paper was to provide evidence about the existence or non-existence of structural breaks in exchange rates series during the transition. For our analysis we used the testing procedure devised by Vogelsang (1997). This technique allows for detecting a break at an unknown date in the trend function of a dynamic univariate time series. The advantage of this procedure is that it does not impose restrictions on the nature of data since it allows trending and unit-root regressors.

The summary of our findings can be divided into three groups associated with particular countries. In the group of countries consisting of the Czech Republic, Hungary, Poland, Slovakia, and Slovenia, the results have shown that these countries either did not experience a structural break in their exchange rates or its effect was quite limited. We have found that the exchange rate behavior in these countries was relatively stable and the measures taken by monetary authorities were executed in a way that in general tended to enhance such stability.

Serious structural breaks were found in the group of Balkan countries that includes Albania, Bulgaria, and Romania. In Albania the structural break was entirely associated with massive devaluation of the exchange rate and revision of its regime. In Romania and Bulgaria the break was allied to other monetary steps with regard to foreign exchange market and price liberalization.

A series of events belonging to an overall monetary reform paired with alterations of exchange rate regime form a complex environment that affected the trend behavior of exchange rates in the group of Baltic states (Estonia, Latvia, and Lithuania). These countries freed themselves from the former Soviet Union and within the scope of monetary reforms re-introduced their national currencies. In case of this group it was not possible to point out at a single event that might cause a structural break. Rather, a combination of monetary steps, some of them having an institutional character, was a cause of it.

We conclude that in less stable economies the measures adopted by monetary authorities were the cause of a structural break in exchange rate behavior. In more stable economies the monetary steps tended to stabilize the exchange rate behavior. 


\begin{tabular}{lrr}
\hline Currency & $\begin{array}{c}\text { US Dollar: } \\
\text { Mean (st.dev.) }\end{array}$ & $\begin{array}{c}\text { Deutsche Mark: } \\
\text { mean (st.dev.) }\end{array}$ \\
\hline Czech Koruna & $28.72(1.93)$ & $18.02(0.52)$ \\
\hline Hungarian Forint & $116.56(38.97)$ & $73.32(23.99)$ \\
\hline Polish Zloty & $2.13(0.73)$ & $1.34(0.46)$ \\
\hline Slovak Koruna & $30.65(1.92)$ & $19.25(1.13)$ \\
\hline Slovenian Tolar & $109.17(41.01)$ & $68.74(25.33)$ \\
\hline Albanian Lek & $102.78(25.98)$ & $64.67(14.09)$ \\
\hline Bulgarian Leva & $292.68(590.62)$ & $172.42(338.51)$ \\
\hline Romanian Leu & $2154.97(2303.06)$ & $1332.07(1335.60)$ \\
\hline Estonian Kroon & $12.64(0.91)$ & $7.97(0.11)$ \\
\hline Latvian Lat & $0.60(0.08)$ & $0.38(0.05)$ \\
\hline Lithuanian Lita & $3.83(0.68)$ & $2.43(0.46)$ \\
\hline
\end{tabular}

Table 2

Basic statistics of real exchange rates

\begin{tabular}{lcc}
\hline Currency & $\begin{array}{c}\text { US Dollar: } \\
\text { Mean (st.dev.) }\end{array}$ & $\begin{array}{c}\text { Deutsche Mark: } \\
\text { mean (st.dev.) }\end{array}$ \\
\hline Czech republic & $24.79(3.59)$ & $15.56(1.95)$ \\
\hline Hungary & $72.93(4.98)$ & $45.87(2.87)$ \\
\hline Poland & $1.12(0.13)$ & $0.70(0.07)$ \\
\hline Slovak republic & $25.46(3.15)$ & $15.99(1.69)$ \\
\hline Slovenia & $59.06(5.10)$ & $37.43(1.72)$ \\
\hline Albania & $26.51(8.11)$ & $16.86(5.36)$ \\
\hline Bulgaria & $15.19(6.86)$ & $9.48(3.96)$ \\
\hline Romania & $144.40(33.26)$ & $91.33(23.16)$ \\
\hline Estonia & $1.83(1.74)$ & $1.16(1.09)$ \\
\hline Latvia & $0.09(0.10)$ & $0.06(0.06)$ \\
\hline Lithuania & $0.28(0.36)$ & $0.18(0.23)$ \\
\hline
\end{tabular}

Table 3

Exchange Rate Regimes 


\begin{tabular}{ll}
\hline $\begin{array}{l}\text { 1. Countr } \\
\mathbf{y}\end{array}$ & Regime \\
\hline Czech Republic & $\begin{array}{l}\text { Fixed (basket peg) since January 1991 to May 1997 } \\
\text { Float from May 1997 }\end{array}$ \\
\hline Hungary & $\begin{array}{l}\text { Adjustable peg (basket peg) since before 1989 } \\
\text { Pre-announced crawling band (peg) since March 1995 }\end{array}$ \\
\hline Poland & $\begin{array}{l}\text { Fixed (basket peg) from January 1990 to October 1991 } \\
\text { Pre-announced crawling peg from October 1991 to May 1995 }\end{array}$ \\
& Float within crawling band from May 1995 to January 1996 \\
& Pre-announced crawling peg from January 1996 \\
\hline Slovakia & Fixed (basket peg) since January 1991 \\
\hline Slovenia & Managed float from October 1991 \\
\hline Albania & Managed float from July 1992 \\
\hline Bulgaria & Managed float from February 1991 \\
& Currency board from July 1997 \\
\hline Romania & Managed float from August 1992 \\
\hline Estonia & Currency board from June 1992 \\
\hline Latvia & Managed float from July 1992 (in reality peg to SDR basket) \\
\hline Lithuania & Float from October 1992 to April 1994 \\
& Currency board from April 1994 \\
\hline
\end{tabular}

Table 4

SupF for nominal exchange rates with respect to US Dollar and Deutsche Mark

\begin{tabular}{lcccc}
\hline Currency & $\begin{array}{c}\text { SupF-stat } \\
\text { for USD }\end{array}$ & Time & $\begin{array}{c}\text { SupF-stat } \\
\text { for DEM }\end{array}$ & Time \\
\hline Czech Koruna & 11.56 & Dec-93 & 6.23 & Apr-97 \\
\hline Hungarian Forint & 5.03 & Jun-97 & $18.13 \mathrm{c}$ & Feb-95 \\
\hline Polish Zloty & 9.24 & Apr-94 & 8.14 & Feb-95 \\
\hline Slovak Koruna & $22.05 \mathrm{a}$ & Jun-93 & 11.13 & Jun-93 \\
\hline Slovenian Tolar & 9.52 & Feb-95 & 13.75 & Feb-92 \\
\hline Albanian Lek & $20.15 \mathrm{~b}$ & Jul-92 & $29.64 \mathrm{a}$ & Jul-92 \\
\hline Bulgarian Leva & $452.71 \mathrm{a}$ & Jan-97 & $331.40 \mathrm{a}$ & Jan-97 \\
\hline Romanian Leu & $53.20 \mathrm{a}$ & Dec-96 & $66.74 \mathrm{a}$ & Dec-96 \\
\hline Estonian Kroon & 7.88 & Feb-95 & $47.46 \mathrm{a}$ & Sep-92 \\
\hline Latvian Lat & $46.29 \mathrm{a}$ & Feb-93 & $31.29 \mathrm{a}$ & Mar-93 \\
\hline Lithuanian Lita & $36.07 \mathrm{a}$ & Dec-92 & $17.77 \mathrm{~d}$ & Sep-93 \\
\hline
\end{tabular}

a, b, c and d denote significance at $1 \%, 2.5 \%, 5 \%$ and $10 \%$ levels, respectively.

Table 5

SupF for real exchange rates with respect to to US Dollar and Deutsche Mark

\begin{tabular}{lcccc}
\hline Currency & $\begin{array}{c}\text { SupF-stat } \\
\text { for USD }\end{array}$ & Time & $\begin{array}{c}\text { SupF-stat } \\
\text { for DEM }\end{array}$ & Time \\
\hline Czech Koruna & 10.26 & Oct-93 & 4.61 & Jun-91 \\
\hline
\end{tabular}




\begin{tabular}{llccc}
\hline Hungarian Forint & 11.17 & May-93 & 9.11 & Feb-95 \\
\hline Polish Zloty & $20.61 \mathrm{~b}$ & Feb-94 & 4.57 & Jul-95 \\
\hline Slovak Koruna & 14.41 & Jun-93 & 7.20 & Aug-92 \\
\hline Slovenian Tolar & 13.60 & Dec-94 & $43.56 \mathrm{a}$ & Aug-92 \\
\hline Albanian Lek & $47.49 \mathrm{a}$ & Jul-92 & $29.64 \mathrm{a}$ & Jul-92 \\
\hline Bulgarian Leva & $36.03 \mathrm{a}$ & May-91 & $24.55 \mathrm{a}$ & Dec-91 \\
\hline Romanian Leu & 12.10 & Nov-91 & 12.94 & Nov-91 \\
\hline Estonian Kroon & $31.26 \mathrm{a}$ & Jul-92 & $53.21 \mathrm{a}$ & Jul-92 \\
\hline Latvian Lat & $25.37 \mathrm{a}$ & Oct-92 & $48.63 \mathrm{a}$ & Sep-92 \\
\hline Lithuanian Lita & $249.02 \mathrm{a}$ & Dec-92 & $355.11 \mathrm{a}$ & Dec-92 \\
\hline
\end{tabular}

a, b, c and d denote significance at $1 \%, 2.5 \%, 5 \%$ and $10 \%$ levels, respectively. 


\section{References}

Bai, J., 1997. "Estimating Multiple Breaks One at a Time," Econometric Theory, 13: 315-52.

Bai, J., and Perron, P., 1995. "Estimating and Testing Linear Models with Multiple Structural Changes," Unpublished manuscript, MIT, September.

Bai, J., and Perron, P., 1998. "Estimating and Testing Linear Models with Multiple Structural Changes," Econometrica, 66: 47-78.

Begg, D., 1996. "Monetary Policy in Central and Eastern Europe," IMF Working Paper 96/108.

Ben-David, D. and Papell D. 1997. "International Trade and Structural Change," Journal of International Economics, 43: 513-523.

Campbell, J. Y. and Perron, P. 1991. "Pitfalls and Opportunities: What Macroeconomist Should Know About Unit Roots," NBER Macroeconomics Annual.

Culver, S. E., and Papell, D. H., 1995. "Real Exchange Rates under the Gold Standard: Can They be Explained by the Trend Break Model?," Journal of International Money and Finance, 14(4): 539-548.

Dickey, D. and Fuller, W. A. 1979. "Distribution of the Estimators for Time Series Regressions with a Unit Root," Journal of the American Statistical Association, 74: 427-431.

Edison, H. J., and Melvin, M. 1990. "The Determinants and Implications of the Choice Of an Exchange Rate System," in W.S. Haraf and T.D. Willet (eds.), Monetary Policy for Volatile Global Economy, Washington, DC, The AEI Press, 1-44.

Edwards, S. 1993. "Exchange-rate Regimes as Nominal Anchors," Weltwirtschaftliches Archiv, 129(1): 1-32.

Flynn, A. N., and Boucher, J. L., 1993. "Tests of Long-Run Purchasing Power Parity Using Alternative Methodologies", Journal of Macroeconomics, 15(1): 109-122.

Hegwood, N. D., and Papell, D. H., 1998. "Quasi Purchasing Power Parity," International Journal of Finance and Economics 3: 279-289.

Ng, S. and Perron, P. 1995. "Unit Root Tests in ARMA Models with Data-Dependent Methods for the Selection of the Truncation Lag," Journal of the American Statistical Association 90: 268-281.

Perron, P., 1989. "The Great Crash, the Oil Price shock, and the Unit Root Hypothesis," Econometrica, 57: 1361-1401. 
Perron, P., and Vogelsang, T., 1992. "Nonstationarity and Level Shifts with an Application to Purchasing Power Parity," Journal of Business and Economic Statistics, 10: 301-20.

Sachs, J., 1996. "Economic Transition and the Exchange-rate Regime," American Economic Review Papers and Proceedings, 86(May): 147-152.

Stock, J. H., and Watson, M. W., 1996. "Evidence and Structural Instability in Macroeconomic Time Series Relations," Journal of Business and Economic Statistics, 14(1): 11-30.

Quirk, P.J. 1994. "Fixed or Floating Exchange-rate Regimes: Does it Matter for Inflation?," IMF Working Paper 94/134.

Vogelsang, T. J. 1997. "Wald-type Tests for Detecting Breaks in the Trend Function of a Dynamic Time Series," Econometric Theory, 13: 818-849.

Wu, Yangru, 1997. "The Trend Behavior of Real Exchange Rates: Evidence from OECD Countries," Weltwirschaftliches Archiv, 133(2): 282-296.

Zivot, E. and Andrews, D. W. K., 1992. "Further Evidence on the Great Crash, the OilPrice Shock, and the Unit-Root Hypothesis," Journal of Business and Economic Statistics, 10(3): 251-270. 